\title{
GAMBARAN SISA KLOR DAN MPN COLIFORM JARINGAN DISTRIBUSI AIR PDAM
}

\author{
Pratiwi Hermiyanti, Endang Tri Wulandari \\ Politeknik Kesehatan Kementerian Kesehatan Surabaya, \\ Jl. Pucang Jajar Tengah 56 Surabaya 60282 \\ pratiwi.kesling@gmail.com
}

\begin{abstract}
PDAM water that has a long distance from the reservoir almost does not smell chlorine so it is possible less than the quality standards can cause the bacteria in the water distribution of PDAM. Purpose of this research to know residual content of chlorine and MPN coliform on PDAM water distribution of Surabaya city 2017. The type of research is observational analytic with cross sectional design. The sampling procedure was performed at 4 locations with replication 3 times morning and daytime. Examination of chlorine residual content using comparator test kit, MPN coliform in laboratory, while $\mathrm{pH}$, water temperature and air temperature is done in the field. Data were analyzed by multiple linear regression test presented in tabular form and analyzed and compared with standard quality standard. The results of the average residual chlorine morning $0,57 \mathrm{mg} / 1$ and daytime $0,5 \mathrm{mg} / 1$, have fulfilled the standard of quality of residual chlorine waste water content that is $0,2-1,0 \mathrm{mg} / 1$. The average MPN coliform in the morning was 8.5 colonies / $100 \mathrm{ml}$ of sample and the daytime was 10.7 colonies / $100 \mathrm{ml}$ of sample, so during the day the sample did not meet the standard quality of MPN coliform of piping water for 10 colonies / $100 \mathrm{ml}$ samples. Average morning $\mathrm{pH} 7.7$ and daytime 7.8, morning water temperature $26.8^{\circ} \mathrm{C}$ and daytime $27.7^{\circ} \mathrm{C}$ and morning air temperature $27.7^{\circ} \mathrm{C}$ and daytime $30,3^{\circ} \mathrm{C}$. The conclusion obtained is the distribution distance affect the residual chlorine content and MPN coliform ( $\mathrm{p}<0,05)$. Suggestion for PDAM is need to be done chlorine addition to active chlorine at furthest point that is 9 kilometers can fulfill requirement.
\end{abstract}

Keywords: Water Distribution Distances, Chlorine Time Remain, MPN Coliform, temperature.

Abstrak: Air hasil olahan PDAM yang memiliki jarak jauh dari reservoir hampir tidak berbau klor sehingga dimungkinkan kurang dari standar baku mutu sehingga menyebabkan adanya bakteri pada distribusi air PDAM. Tujuan penelitian adalah mengetahui kadar sisa klor dan MPN coliform pada distribusi air PDAM Kota Surabaya tahun 2017. Jenis penelitian adalah analitik observasional dengan desain cross sectional. Prosedur pengambilan sampel dilakukan pada 4 lokasi dengan replikasi 3 kali pagi dan siang hari. Pemeriksaan kadar sisa klor menggunakan komparator test kit, MPN coliform pada laboratorium, sedangkan $\mathrm{pH}$, suhu air dan suhu udara dilakukan di lapangan. Data dianalisis dengan uji regresi linier ganda yang disajikan dalam bentuk tabel dan dianalisis serta dibandingkan dengan standar baku mutu. Hasil penelitian rata-rata sisa klor pagi hari $0,57 \mathrm{mg} / 1$ dan siang hari $0,5 \mathrm{mg} / \mathrm{l}$, telah memenuhi standar baku mutu kadar sisa klor air perpipaan yaitu $0,2-1,0 \mathrm{mg} / \mathrm{l}$. Rata-rata MPN coliform pagi hari $8,5 \mathrm{koloni} / 100 \mathrm{ml}$ sampel dan siang hari 10,7 koloni/ $100 \mathrm{ml}$ sampel, sehingga pada siang hari sampel belum memenuhi standar baku mutu MPN coliform air perpipaan sebesar 10 koloni/ 100 $\mathrm{ml}$ sampel. $\mathrm{pH}$ rata-rata pagi hari 7,7 dan siang hari 7,8 , suhu air pagi hari $26,8^{\circ} \mathrm{C}$ dan siang hari $27,7^{\circ} \mathrm{C}$ dan suhu udara pagi hari $27,7^{\circ} \mathrm{C}$ dan siang hari $30,3^{\circ} \mathrm{C}$. Jarak distribusi mempengaruhi kadar sisa klor dan MPN coliform $(\mathrm{p}<0,05)$. Saran bagi PDAM adalah perlu dilakukan penambahan klor agar klor aktif pada titik terjauh yaitu $9 \mathrm{~km}$ dapat memenuhi syarat.

Kata Kunci: Jarak Distribusi Air PDAM, Kadar Sisa Klor, MPN Coliform, suhu 
Perusahaan Daerah Air Minum (PDAM) sebagai pelaksana penyediaan air bersih harus memenuhi persyaratan air minum ditinjau dari segi kualitas maupun kuantitas sesuai dengan Peraturan Menteri Kesehatan RI Nomor 492/Menkes/Per/IV/2010 dengan tentang persyaratan kualitas air minum bahwa persyaratan kualitas air minum harus memenuhi persyaratan kesehatan yang meliputi persyaratan fisika, kimiawi, mikrobiologi dan radioaktif. Dengan melaksanakan Permenkes tersebut diharapkan penyebaran penyakit menular melalui media air yang dalam hal ini adalah penyakit perut dapat ditekan seminimal mungkin.

Umumnya PDAM melakukan desinfeksi dengan menambahkan klor ke dalam air yang akan didistribusikan. Namun karena adanya karakteristik saat proses desinfeksi maka klorakan mudah menguap dan berikatan dengan senyawa organik atau anorganik yang dapat berakibat pada terbentuknya senyawa lain yang dapat berbahaya bagi konsumen. Sifat klor yang mudah menguap tersebut mengakibatkan kandungan klor yang ada dalam air akan berkurang/turun (Budiyono, 2013:110).

Peraturan Menteri Kesehatan RI Nomor 736/MENKES/PER/VI/2010 tentang tata laksana pengawasan kualitas air minum pada lampiran menyatakan bahwa sisa klor pada air minum dengan sistem jaringan perpipaan memiliki nilai minimal $0,2 \mathrm{mg} / \mathrm{l}$ dan nilai maksimal 1,0 $\mathrm{mg} / \mathrm{l}$ pada unit distribusi. Berdasarkan Permenkes Republik Indonesia Nomor. 416/MENKES/PER/IX/1999 tentang syarat-syarat dan pengawasan kualitas air pada lampiran menyatakan bahwa total bakteri coliform pada air perpipaan memiliki kadar maksimum yang diperbolehkan yaitu 10 jumlah per $100 \mathrm{ml}$ sampel. Apabila kandungan sisa klor di bawah batas standar dapat menyebabkan berkembangnya mikroorganisme patogen dalam air yang tidak bisa dihambat. Disisi lain apabila pembubuhan klorberlebihan maka akan menyebabkan rasa dan bau yang tidak menyenangkan. Serta klor dapat membentuk senyawa organik terklorinasi yang bisa bersifat racun terhadap ikan ataupun potensial bersifat karsinogenik (kanker), iritasi mata, kulit, dan saluran pernafasan bagi manusia (Budiyono, 2013:110).

Berdasarkan uji petik yang telah dilakukan pada reservoir dan pelanggan pada kran air dengan jarak $3 \mathrm{~km}$, dan $6 \mathrm{~km}$ dari PDAM, air yang didistribusikan memiliki tanda-tanda adanyakloryang tinggi. Sehingga air yang ditampung untuk memasak masih memerlukan proses deklorinasi untuk mengurangi adanya klor selama beberapa jam hingga 1 hari sampai 2 hari kemudian air baru bisa digunakan. Sedangkan pada pelanggan yang memiliki jarak sekitar $9 \mathrm{~km}$ dari reservoir PDAM memiliki kondisi air yang sedikit berbauklorsehingga air dapat langsungdipergunakan.

Tujuan pada penelitian ini adalah menganalisa pengaruh jarak distribusi PDAM terhadap kadar sisa klor dan MPN Coliform.

\section{BAHAN DAN CARA KERJA}

Jenis penelitian ini merupakan penelitian analitik observasional dengan desain cross sectional yang menganalisa pengaruh jarak distribusi PDAM terhadap kadar sisa klor dan MPN Coliform pada titik 0, 3, 6, $9 \mathrm{~km}$ dari reservoir PDAM. Pengambilan sampel dilakukan dengan replikasi sebanyak 3 (tiga) kali yaitu 3 hari dengan waktu dan tempat pengambilan sampel yang sama, replikasi dilakukan karena pemberian klor yang terus menerus menyebabkan fluktuatif sehingga trend yang didapatkan setiap harinya berbeda. Pengambilan sampel dilakukan pada reservoir dan kran air pelanggan selama tiga hari berturut-turut setiap pagi dan siang hari. Pengambilan sampel dilakukan pagi dan siang hari dikarenakan tekanan air yang disuplai tidak stabil sehingga rentang 
perbedaan tekanan air cukup banyak antara pagi dan siang (penggunaan air oleh pelanggan yang mempengaruhi perbedaan tekanan). Analisa data menggunakan regresi liner berganda.
HASIL DAN PEMBAHASAN

Kadar Sisa Klor

Hasil pengukurankadarsisa klor, $\mathrm{pH}$, suhu air dan udara pada reservoir dan kran air pelanggan PDAM yang dijelaskan pada tabel di bawah ini:

HASIL PENGUKURAN SUHU AIR, pH, SISA KLOR DI RESERVOIR DAN KRAN AIR PELANGGAN PDAM SURABAYA TAHUN 2017

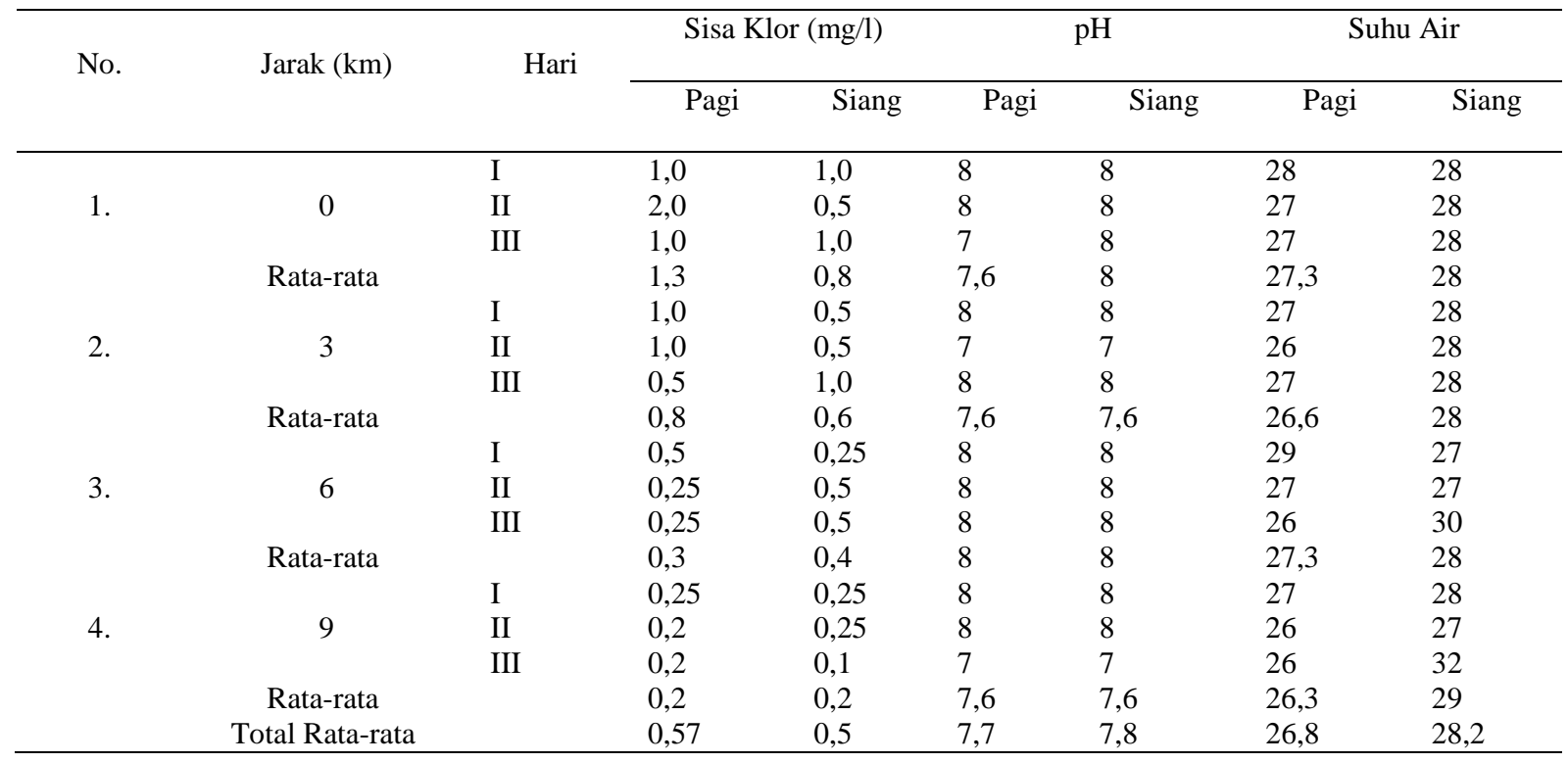

Pengukuran sisa klor yang dilaksanakan selama tiga hari berturutturut didapatkan hasil rata-rata akhir sisa klor pada pagi hari sebesar $0,57 \mathrm{mg} / \mathrm{l}$ sedangkan pada siang hari sisa klor sebesar 0,5 mg/l. Pengukuran kadar sisa klor pada hari pertama hingga hari ketiga memiliki hasil rata-rata yang berbeda baik pagi hari maupun siang hari. Kadar sisa klor hari pertama hingga hari ketiga tidak memiliki jarak perbedaan yang terlalu besar. Kadar sisa klor pagi hari pada hari pertama yaitu $0,6 \mathrm{mg} / \mathrm{l}$, untuk hari kedua $0,8 \mathrm{mg} / \mathrm{l}$, dan untuk hari ketiga $0,4 \mathrm{mg} / \mathrm{l}$. Rentang jarak perbedaan yang didapatkan setiap harinya antara 0,2- 0,4 mg/l. Sedangkan pada siang hari untuk hari pertama kadar sisa klor yang didapatkan sebesar $0,5 \mathrm{mg} / \mathrm{l}$, untuk hari kedua $0,4 \mathrm{mg} / \mathrm{l}$ dan untuk hari ketiga $0,6 \mathrm{mg} / \mathrm{l}$. Sehingga Rentang jarak perbedaan setiap harinya yang didapatkan antara $0,1-0,2 \mathrm{mg} / \mathrm{l}$. Berdasarkan hasil penelitian Afrianita (2016) bahwa pada enam titik pengukuran tidak masuk kedalam rentang persyaratan pada outlet reservoir $1 \mathrm{mg} / \mathrm{l}$ dan minimum $0,2 \mathrm{mg} / \mathrm{l}$ sebesar 26,1\% dan sebanyak 73,9\% wilayah telah memenuhi baku mutuwilayah yang memiliki kadar sisa klor di bawah baku mutu berada pada jarak 3 $6 \mathrm{~km}$. Didukung oleh hasil penelitian Abdi (2015) dengan simulasi menggunakan injeksi konsentrasi klor di awal distribusi air sebesar 10,34 mg/l maka akan dihasilkan sisa klor yang bervariasi dari $0,2-1,0 \mathrm{mg} / \mathrm{l}$. Pada simulasi ini pelanggan yang dekat dengan reservoir memiliki sisa klor yang cukup tinggi yaitu diatas 0,5 $\mathrm{mg} / \mathrm{l}$ sehingga berdampak negatif untuk pelanggan karena sisa klor yang tinggi dapat bereaksi dengan bahan organik dalam air yang mengakibatkan terjadinya 
korosi pada pipa dan air dapat menjadi karsinogenik. Sedangkan dalam simulasi dengan injeksi klor di awal sebesar 0,8 mg/l maka akan dihasilkan sisa klor yang memenuhi batas sisa klor yang diijinkan yaitu $0,2-0,5 \mathrm{mg} / \mathrm{l}$ namun itu hanya terjadi pada pelanggan yang dekat dengan reservoir. Untuk pelanggan yang jauh dari reservoir kurang dari $0,2 \mathrm{mg} / \mathrm{l}$. Hal ini juga berdampak negatif karena bakteri patogen dalam air masih tersisa.

Hasil yang didapatkan dari beberapa penelitian tersebut sesuai dengan pengukuran sisa klor pada PDAM Surabaya. Dimana injeksi klor di awal terlalu besar sehingga menyebabkan kadar sisa klor cukup tinggi pada pelanggan yang dekat dengan reservoir. Sehingga kadar sisa klor yang tinggi perlu dilakukan proses deklorinasi sedangkan pada kadar sisa klor yang rendah perlu dilakukan reklorinasi. Pada perbedaan kadar sisa klor untuk hari pertama hingga ketiga disebabkan karena injeksi klor dan tekanan air yang berbeda. Hal ini disebabkan oleh water age (usia air) yaitu waktu yang dihabiskan oleh bagian dari air dalam jaringan. Usia air dipengaruhi oleh kebutuhan air pelanggan yaitu jumlah air perliter yang digunakan pada setiap waktu yang berbeda. Dalam 24 jam pemakaian air tiap jam berbeda, hal ini disebabkan oleh aktivitas serta kebutuhan air pelanggan yang berbeda tiap waktu. Usia air merupakan faktor dalam penurunan kualitas air dalam sistem distribusi. Hal itu disebabkan oleh interaksi antar dinding pipa dan air serta reaksi air dalam pipa. Dalam perjalanan air di dalam pipa selama sistem distribusi air mengalami reaksi kimia, fisik, dan biologi. Sehingga semakin lama air berada dalam jaringan maka semakin banyak reaksi yang terjadi pada air di dalam sistem sehingga membuat kualitas air berubah.

Pengukuran sisa klor sangat dipengaruhi oleh parameter $\mathrm{pH}$ karena proses desinfeksi membutuhkan nilai $\mathrm{pH}$ yang sesuai dengan standar baku mutu yang telah ditetapkan. Apabila nilai $\mathrm{pH}$ tidak memenuhi persyaratan maka proses desinfeksi tidak akan berjalan secara efektif. Rata-rata $\mathrm{pH}$ dari pengukuran yang telah dilakukanq selama 3 hari yaitu 7,7 pada pagi hari sedangkan pada siang hari didapatkan nilai $\mathrm{pH}$ sebesar 7,8. $\mathrm{pH}$ yang didapatkan telah memenuhi persyaratan, sesuai Peraturan Menteri Kesehatan Republik Indonesia Nomor 416 tahun 1999 tentang Syarat-syarat Dan Pengawasan Kualitas Air dimana kadar minimum dan maksimum yang diperbolehkan adalah 6,5 - 9,0. Kegunaan pengaturan $\mathrm{pH}$ dalam instalasi air minum bertujuan untuk mengendalikan korosif perpipaan dalam sistem distribusi (Triatmaja, 2006). Berdasarkan penelitian Afrianita (2016) hasil pemeriksaan sisa klor $0,479 \mathrm{mg} / \mathrm{l}$ dengan $\mathrm{pH}$ sebesar 7,27 dan sisa klor 0,142 $\mathrm{mg} / \mathrm{l}$ dengan nilai $\mathrm{pH} 8,12$. Hasil tersebut sejalan dengan penelitian Asryadin (2012) bahwa sisa klor akan semakin menurun seiring naiknya nilai $\mathrm{pH}$ dengan hasil pemeriksaan sisa klor sebesar $0,45 \mathrm{mg} / \mathrm{l}$ pada kondisi pH sebesar 8,575. Perubahan $\mathrm{pH}$ dalam air berhubungan dengan daya kerja klor. Dari hasil pengukuran $\mathrm{pH}$ tersebut menunjukkan bahwa proses desinfeksi yang telah dilakukan berjalan secara efektif karena kondisi air berada pada suasana basa lemah. Tidak begitu banyak perbedaan $\mathrm{pH}$ dari pengukuran yang dilakukan. Pengukuran selama 3 hari menunjukkan bahwa proses desinfeksi berjalan stabil sehingga tidak merubah nilai $\mathrm{pH}$ secara signifikan. $\mathrm{pH}$ akan mengontrol jumlah $\mathrm{HOCl}$ (asam hipoklorit) dan $\mathrm{OCl}^{-}$(ion hipoklorit) dalam larutan. Pada proses desinfeksi dengan klor, kontaminasi mikroorganisme meningkat sejalan dengan kenaikan $\mathrm{pH}$. Klorinasi efektif pada $\mathrm{pH}$ netral atau basa lemah, sedangkan pada $\mathrm{pH}$ basa $(>8,5)$ daya desinfeksi klor akan berkurang. Pengolahan air memerlukan $\mathrm{pH}$ netral dimana dengan $\mathrm{pH}$ tersebut pengolahan dapat dilakukan secara efektif. 
Parameter suhu air juga dapat mempengaruhi proses desinfeksi dimana diatur pada Peraturan Menteri Kesehatan Republik Indonesia Nomor 416 tahun 1999 tentang Syarat-syarat Dan Pengawasan Kualitas Air untuk parameter suhu udara memiliki baku mutu sebesar $\pm 3^{\circ} \mathrm{C}$.Dari hasil pengukuran suhu air pada pagi hari sebesar $26,8^{\circ} \mathrm{C}$ dan pada siang hari suhu air sebesar $28,2^{\circ} \mathrm{C}$ sedangkan untuk suhu udara pada pagi hari sebesar $27,7^{\circ} \mathrm{C}$ dan pada siang hari sebesar $30,3^{\circ} \mathrm{C}$. Sehingga dari nilai yang didapatkan tersebut pada pagi hari sudah memenuhi syarat $\pm 3^{\circ} \mathrm{C}$ sedangkan untuk siang hari belum memenuhi syarat. Sesuai dengan hasil penelitian Asryadin (2012) memperoleh hasil pemeriksaan suhu air perpipaan yang meningkatkan di jaringan distribusi, tetapi tidak signifikan. Suhu meningkat sebesar $0,6^{\circ} \mathrm{C}$ pada sisa klor $0,45 \mathrm{mg} / \mathrm{l}$ sampai $0,0975 \mathrm{mg} / \mathrm{l}$. Sehingga semakin tinggi nilai suhu dalam air minum, kadar sisa klor akan semakin menurun. Berbeda dengan penelitian Triatmadja (2006) yang menyatakan terjadi penurunan efisiensi natrium hipoklorit berdasarkan perbedaan suhu yaitu pada suhu $10^{\circ} \mathrm{C}$ terjadi penurunan $0,1 \mathrm{mg} / \mathrm{l}$, suhu $20^{\circ} \mathrm{C}$ terjadi penurunan $1,1 \mathrm{mg} / \mathrm{l}$ serta pada suhu $25^{\circ} \mathrm{C}$ terjadi penurunan $2 \mathrm{mg} / \mathrm{l}$. Data ini menunjukkan bahwa semakin tinggi suhu air peluruhan klor semakin besar. Perbedaan hasil dapat diakibatkan oleh beberapa kondisi seperti pengukuran yang menggunakan thermometer dengan ketelitian rendah dan kondisi perpipaan yang terdapat di lokasi sampling karena selain $\mathrm{pH}$ dan suhu, jenis pipa juga ikut mempengaruhi kadar sisa klor di jaringan distribusi. Suhu yang lebih dari $30^{\circ} \mathrm{C}$ memiliki tingkat suhu yang lebih tinggi sehingga kurang efektif dalam proses desinfeksi dan pengaruh suhu yang sesuai dapat menyebabkan bakteri MPN coliform bertahan selama beberapa hari tergantung juga dari kondisi lingkungannya (Ali, 2010).

\section{Kandungan MPN Coliform}

Tabel 2. Hasil Pengukuran MPN Coliform Di Reservoir Dan Kran Air Pelanggan PDAM Surabaya

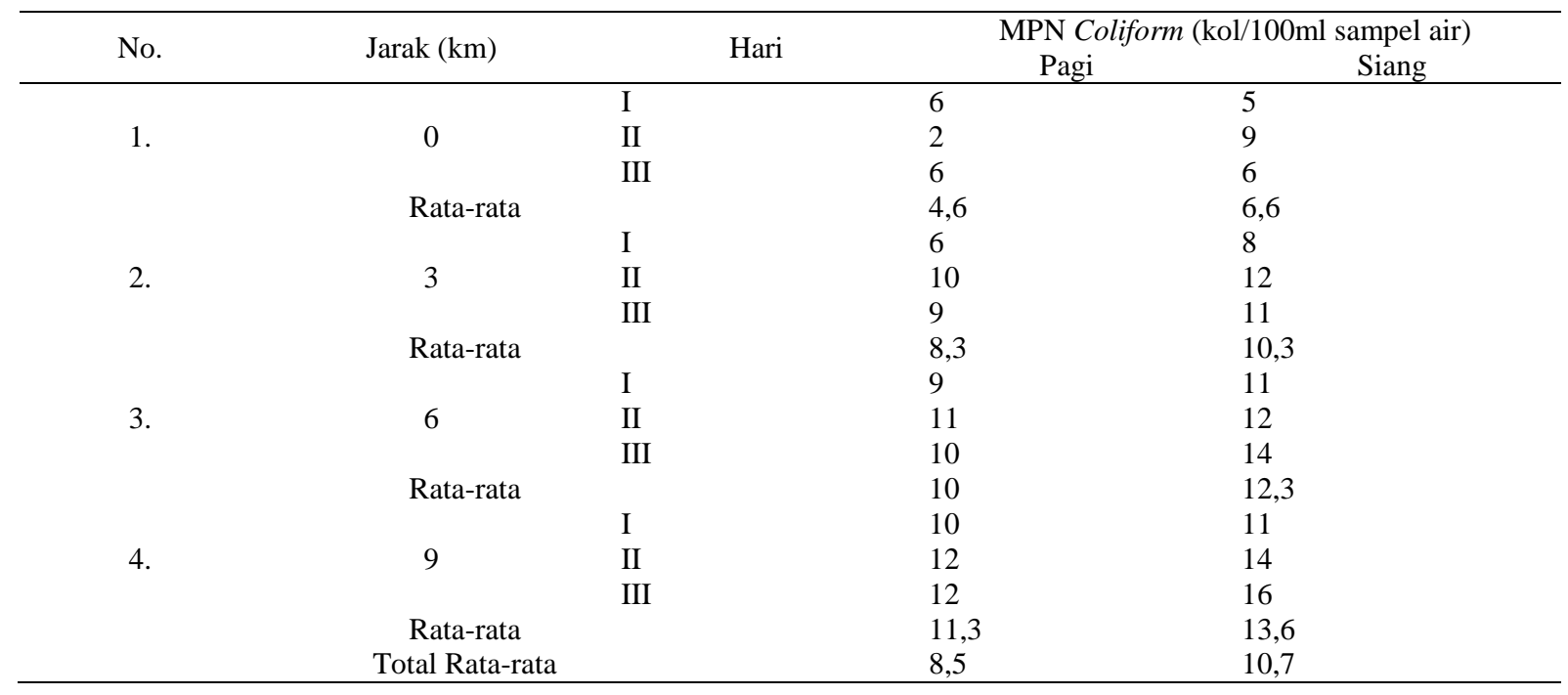


Pengukuran koloniMPN coliform yang dilaksanakanselama 3 hari berturutturut dapat diketahui rata-rata akhir dari koloniMPN coliform pada pagi hari sebesar 8,5 koloni/100 ml sampel sedangkan pada siang hari sebesar 10,7 koloni/100 ml sampel. Dari pengukuran MPN coliform tersebut dapat dibandingkan antara hari pertama hingga hari ketiga, dimana MPN coliform memiliki hasil ratarata yang berbeda baik pagi hari maupun siang hari. Hasil nilai yang didapatkan antara hari pertama hingga hari ketiga tidak memiliki jarak perbedaan yang terlalu besar. Nilai MPN coliform yang didapatkan pada hari pertama saat pagi hari yaitu 7,7 koloni/100 ml sampel, untuk hari kedua 8,7 koloni/100 ml sampel, dan untuk hari ketiga 9,2 koloni/100 ml sampel, rentang jarak perbedaan yang didapatkan setiap

harinya antara $1-2$ koloni/100 ml sampel. Pada hari pertama siang hari MPN coliform yang didapatkan sebesar 8,7 koloni/100 ml sampel, hari kedua 11,7 koloni/100 ml sampel dan hari ketiga 11,7 koloni/100 $\mathrm{ml}$ sampel sehingga rentang jarak perbedaan setiap harinya yang didapatkan antara 2 koloni/100 ml sampel. Berdasarkan hasil penelitian Sunardi (2014), perbedaan tersebut kemungkinan disebabkan karena adanya konsentrasi kadar sisa klor yang berbeda pada air karena pembubuhan klor dilakukan secara terus menerus sehingga menyebabkan fluktuatif untuk setiap harinya maka kandungan MPN coliform juga berbeda untuk setiap harinya, dimana ada tidaknya MPN coliform tergantung dengan adanya sisa klor dalam air.

Parameter $\mathrm{pH}$ juga mempengaruhi adanya koloni MPN coliform, namun dari hasil pengukuran yang didapatkan nilai $\mathrm{pH}$ pada pagi hari sebesar 7,7 dan pada siang hari $\mathrm{pH}$ sebesar 7,8 sedangkan standar baku mutu yang ditetapkan $\mathrm{pH}$ sebesar 6,5 - 9,0 sehingga $\mathrm{pH}$ telah memenuhi persyaratan. Namun nilai $\mathrm{pH}$ tidak selalu stabil. Sesuai dengan hasil penelitian
Triatmaja (2006) variasi perubahan nilai $\mathrm{pH}$ tersebut secara langsung tidak dipengaruhi oleh jarak distribusi air dalam sistem perpipaan, perubahan yang terjadi dapat disebabkan karena adanya pipa distribusi air yang rusak atau bocor sehingga memungkinkan suplai air dari luar yang dapat menyebabkan pencemaran air dan peningkatan jumlah dan aktifitas mikroorganisme terutama bakteri dalam metabolisme hidupnya sehingga memberi kontribusi dalam menyebabkan perubahan nilai $\mathrm{pH}$ struktur kimia enzim. Ketika enzim pada mikroorganisme kontak dengan klor, satu atau lebih dari atom hidrogennya akan diganti oleh ion klor.

\section{Hubungan jarak distribusi terhadap kadar sisa klor dan MPN Coliform}

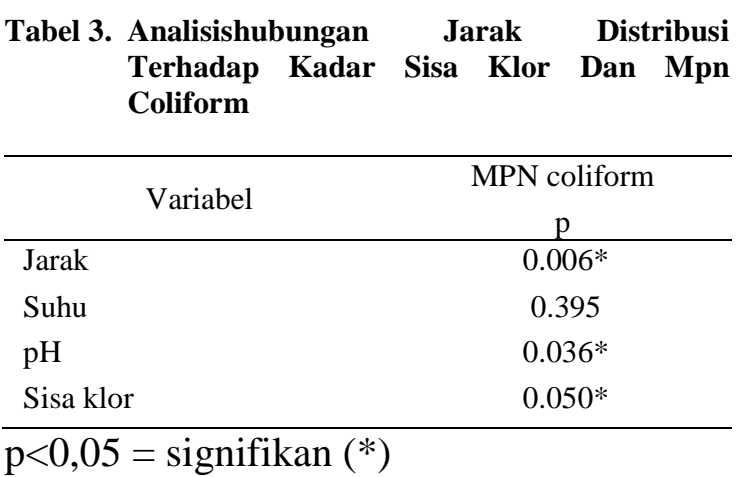

Jarak distribusi air yang semakin jauh menyebabkan penurunan kadar sisa klor dalam air hingga menuju ke pelanggan. Sesuai dengan hasil penelitian yang dilakukan oleh Asryadin (2012), penurunan kadar sisa klor bebas akan berkurang selama perjalanan air sampai ke konsumen yang jauh. Semakin rendahnya sisa klor dalam distribusi air, kandungan MPN coliform semakin tinggi.

Klor yang dimasukkan ke dalam air, pertama kali akan bereaksi dengan senyawa kimia karena klor bersifat sebagai oksidator yang kuat. Kemudian klor bereaksi dengan mikroorganisme sebagai desinfektan untuk membunuh bakteri.. Daya desinfeksi klor di dalam air didasarkan pada kekuatan oksidasi dari 
atom oksigen bebas dan reaksi substitusi oleh klor. Klor mampu membunuh mikroorganisme patogen seperti virus dan bakteri dengan cara memecah ikatan kimia pada molekulnya seperti merubah struktur ikatan enzim, bahkan merusak Hal ini dapat menyebabkan berubahnya ikatan kimia pada enzim tersebut atau bahkan memutus ikatan kimia enzim, sehingga enzim pada mikroorganisme tidak dapat berfungsi dengan baik dan sel atau bakteri akan mengalami kematian. Penelitian serupa juga dilakukan oleh Syahputra (2012), kecenderungan semakin jauh antara reservoir dengan konsumen maka semakin kecil atau semakin sedikit sisa klor bebas. Berdasarkan pengukuran sisa klor yang dilakukan selama 3 hari berturutturut didapatkan hasil bahwa terdapat kesesuaian antara jarak distribusi dengan adanya kadar sisa klor dalam air. Perubahan atau penurunan kadar sisa klor terjadi akibat banyaknya mikroorganisme sebagai kontaminasi air dalam sistem perpipaan. Berdasarkan hasil observasi diperoleh informasi bahwa air PDAM yang mengalir ke titik paling jauh dalam pendistribusiannya tidak terdapat sarana atau lokasi penambahan klor sehingga tidak ada suplai tambahan klor aktif dalam air. Faktor yang mempengaruhi penurunan sisa klor di jaringan distribusi seperti kondisi pipa dan kondisi lingkungan di masing-masing wilayah. Pada jarak distribusi yang sama, memiliki konsentrasi sisa klor yang berbeda serta pada jarak yang lebih jauh sisa klor tetap sama. Hal

\section{DAFTAR RUJUKAN}

Ali, Munawar, 2010. Peran Proses Desinfeksi Dalam Upaya Peningkatan Kualitas Produk Air Bersih. Surabaya. UPN Press. Cetakan I.

Budiyono, dan Siswo Sumardiono, 2013. Teknik Pengolahan Air. Yogyakarta, Graha Ilmu. Edisi Pertama.

Kementerian Kesehatan, 2010, Permenkes RI Nomor 736/MENKES/PER/VI/2010 Tentang Tata Laksana Pengawasan Kualitas Air Minum. ini dapat diakibatkan dari keadaan pipa dan lingkungan yang dilewatinya. Bakteri dapat masuk bersama air tanah atau air hujan yang terkontaminasi ke dalam pipa melalui celah sambungan dan pipa yang bocor. Material pipa dapat menjadi media pertumbuhan dengan menggunakan senyawa-senyawa organik sebagai nutrisi untuk pertumbuhan bakteri. Berdasarkan penelitian Afrianita (2016) sisa klor yang terdapat dalam pipa distribusi akan bereaksi untuk membunuh bakteri-bakteri yang tumbuh di sepanjang dinding pipa tersebut, sehingga kadar sisa klor akan semakin menurun terhadap jarak. Oleh karena itu pada terdapat keterkaitan antara jarak dengan MPN coliform dimana semakin jauh jarak distribusi air maka kontaminasi semakin tinggi. Dari ketiga parameter tersebut menunjukkan saling keterkaitan antara jarak distribusi dengan sisa klor dan adanya MPN coliform

\section{KESIMPULAN}

Kadar sisa klor pada pagi dan siang hari telah memenuhi standar baku mutu Permenkes736/MENKES/PER/VI/2010.M PN coliform pada pagi hari telah sesuai dengan standar baku mutu sedangkan pada siang hari belum sesuai standar baku mutu sesuai dengan nomor Permenkes 416/MENKES/PER/IX/1999. Jarak pada distribusi yang mempengaruhi secara signifikan terhadap kadar sisa klor serta kandungan MPN coliform pada air perpipaan.

Syahputra, Benny, 2012. Analisa Sisa Chlor Pada Jaringan Distribusi Air Minum PDAM Kota Semarang. http: //lingkungan. abu.fadiyah.ac.id/images/fileTL/UNISSULA_ SNST 3.pdf. Diakses pada tanggal 20 Juni 2017.

Sunardi, 2014. Pemeriksaan Most Probable Number (MPN) Bakteri Coliform Dan Coli Tinja Pada Jamu Gendong Yang Dijual Di Pasar Besar Kota Palangkaraya.http://www. umpalangkaraya. ac.Id/ perpustakaan/ 
digilib/files/disk1/7/123-dfadf-sunardinpm328-1-ktisuna-1.pdf. Diakses pada tanggal 27 Desember 2016.

Triatmadja, R. 2006. Pra Analisa Pada Jaringan Pipa Untuk Meningkatkan Kecepatan
Komputasi. http: //lingkungan. ijfvdh.dfgd ac.id/ images/ fileTL/UGM.Yogyakarta 4.pdf. Diakses pada tanggal 18 Juni 2017. 